\title{
A Membraneless Alkaline Direct Liquid Fuel Cell (DLFC) Platform Developed with a
}

Catalyst-Selective Strategy

Xingwen Yu, ${ }^{1}$ Emilio J. Pascual, ${ }^{1}$ Joshua C. Wauson, ${ }^{1}$ and Arumugam Manthiram ${ }^{1, *}$ Electrochemical Energy Laboratory \& Materials Science and Engineering Program

The University of Texas at Austin,Austin, TX 78712, USA

Xingwen Yu:xyu@utexas.eduEmilio J. Pascual: emilio.pascual@utexas.edu

Joshua C. Wauson: jcwauson@gmail.com

Arumugam Manthiram: manth@austin.utexas.edu

\section{ABSTRACT}

With a logical management of the catalyst selectivity, we present a scalable, membraneless alkaline direct liquid fuel cell (DLFC) platform. The uniqueness of this innovation is that the inexpensive (non-platinum) cathode catalysts, based on strongly coupled transitionmetal-oxide nanocrystals and nano-structured carbon materials (e. g., $\mathrm{NiCo}_{2} \mathrm{O}_{4}$ nano-particles on a nitrogen-doped graphene and $\mathrm{MnNiCoO}_{4}$ nano-particles on a nitrogen-doped multi-wall carbon nanotube), exhibit high activity for the oxygen reduction reaction (ORR) but without activity for the anode fuel oxidation reaction (FOR). Therefore, operation of the DLFCs allows the anode fuel to freely enter the cathode. This strategy avoids the reliance on expensive or difficult-todevelop cation- or anion-exchange membranes and circumvents the scalability concerns of the conventional membraneless DLFCs that are operated under a laminar-flow principle. With proper catalyst selectivity, a variety of organic liquids can be used as anode fuels. The high power density delivered by the membraneless DLFCs with inexpensive components and safe fuels can enable the development of not only small-scale portable power sources but also largescale energy generation systems for transportation and stationary storage.

Keywords:Membraneless direct liquid fuel cell, alkaline fuel cell, catalyst selectivity, transitionmetal-oxide nano crystals, nano-structured carbon materials

*Corresponding author: Tel: +1-512-471-1791; fax: +1-512-471-7681.

E-mail address: manth@austin.utexas.edu (A. Manthiram) 


\section{Introduction}

The driver for the advancement of direct liquid fuel cell technology (DLFC) is the need and desire for sustainable energy resources. Currently, the sluggish kinetics of electrode reactions (reliance on the high-loading, expensive platinum-based cathode catalyst) and the high cost of Nafion ${ }^{\circledR}$ membrane are the major concerns associated with the low-temperature DLFCs based on proton exchange membranes (PEM) [1-4]. One approach to enhance the electrode reaction kinetics is to operate the DLFCs in alkaline media $[5,6]$. However, a practically viable alkaline anion-exchange membrane (AEM) has yet to be developed to meet the demand of the DLFCs.

Development of membraneless DLFCs can avoid the necessity of any ion-exchange membrane. Previously, the membraneless fuel cells were developed mainly based on a laminar-flow principle or integration of the fuel-tolerant cathode catalysts while manipulating the non-mixture laminar-flow of the fuel and the air (as illustrated in Fig. S1). Advances in the laminar-flow fuel cells for electrochemical conversion have recently been reviewed $[7,8]$. These laminar-flow fuel cells can generally be classified as liquid/liquid reactants fuel cells (with small-molecule organic liquids as an anode fuel and liquid-phase oxidants such as hydrogen peroxide, vanadate, and potassium permanganate)[9-11] and liquid/gaseous reactants fuel cells (with small-molecule organic liquids as an anode fuel and gas-phase oxidant typically air or oxygen) [12-16]. However, due to the limitation of the laminar-flow behavior, this type of membraneless fuel cells are difficult to be scaled up for a single cell (can be built only to millimeter-scale size), thus limiting their practical applications.Recently, alternative strategies rather than the single cell scale-up have been proposed and endeavored to maximize the actual power output of theflow cell systemsthrough 
stacking or multiplexing approaches $[17,18]$. However, the larger power output achieved was proportional to the cost of the microfluidic channel area, which makes these approaches impractical.

The concept of "mixed reactant fuel cells" has been recently proposed and studied mainly with the methanol fuel (MR-DMFC) [19-22].This type of fuel cell is generally operated based onmethanol-tolerant oxygen reduction reaction (ORR) catalysts. So far, a variety of cathode catalysts that can tolerate methanol at a certain level have been studied, including (i) small-particle or amorphous platinum catalysts [23, 24], (ii) Pt-Fe/C and Pt$\mathrm{Co} / \mathrm{C}$ catalysts [25-27], (iii)FeTMPP(iron tetramethoxyphenylporphyrin) [28, 29], and (iv) ruthenium-based (Ru-Mo-S, Ru-S, and RuSe) catalysts[30-33].However, the performances of this type of fuel cell was not comparable to the membrane-based DMFCs due to the lack of satisfactory cathode catalysts with high catalytic selectivity.

In view of the above discussions, the low-temperature DLFC technologies are actually in a challenging situation. Development of practically viable DLFCs is currently facing a sequence of challenges due to the (i) high cost of the cell components (PEMbased DLFCs), (ii) lack of reliable and viable AEMs (alkaline DLFCs), (iii) limitation in the scalability (laminar-flow membraneless DLFCs) or (iv) lack of highly selective cathode catalysts (mixed reactant fuel cells). Inspired by the studies with the MR-DMFCs and our recent observation that the oxidation reaction of a small-molecule organic salt, potassium formate, does not occur on some highly active oxygen reduction reaction (ORR) catalysts $[34,35]$, we report here a scalable membraneless alkaline DLFC platform with a strategic approach (catalyst-selective strategy) to break through the currently existing "bottle-neck" obstacles of the DLFC technology. With the two non-platinum highly selective 
cathode catalysts $\mathrm{NiCo}_{2} \mathrm{O}_{4} / \mathrm{N}$-graphene $\left(\mathrm{NiCo}_{2} \mathrm{O}_{4}\right.$ nano-particles on a nitrogen-doped graphene) and $\mathrm{MnNiCoO}_{4} / \mathrm{N}-\mathrm{MWCNT}\left(\mathrm{MnNiCoO}_{4}\right.$ nano-particles on a nitrogen-doped multi-wall carbon nanotube), four membraneless DLFC systems are demonstrated with the organic liquids methanol, ethanol, ethylene glycol, and glycerol as anode fuels.

\section{Experimental}

\subsection{Synthesis of graphene material}

The graphene material was synthesized from natural graphite with the following procedure. (i) $2.0 \mathrm{~g}$ of graphite powder (SP-1, Bay Carbon, MI) and $1.0 \mathrm{~g}$ of $\mathrm{NaNO}_{3}$ (Aldrich, $>99 \%$ ) were mixed and dissolved/dispersed into $96 \mathrm{~mL}$ of concentrated $\mathrm{H}_{2} \mathrm{SO}_{4}$ (Fisher Scientific, 98\%) with an ice bath. (ii) Under vigorous stirring, $6.0 \mathrm{~g}$ of $\mathrm{KMnO}_{4}$ (Fisher Scientific, 99.6\%) was gradually added. The temperature of the mixture was maintained below $20{ }^{\circ} \mathrm{C}$ with an ice bath. (iii) After removing the ice bath, the mixture was stirred at $35^{\circ} \mathrm{C}$ in a silicon oil bath for $18 \mathrm{~h}$. As the reaction progressed, the mixture became pasty with a brownish color. (iv) Successively, 150 $\mathrm{mL}$ of deionized water was slowly added to the above pasty mixture. Addition of water into the concentrated $\mathrm{H}_{2} \mathrm{SO}_{4}$ medium releases a large amount of heat, so an ice bath was necessary to maintain the temperature below $50{ }^{\circ} \mathrm{C}$. (v) After further dilution with $500-600 \mathrm{~mL}$ of water, 5.0 $\mathrm{mL}$ of $30 \% \mathrm{H}_{2} \mathrm{O}_{2}$ (Fisher Scientific) was added to the mixture. The color of the diluted solution changed to brilliant yellow along with bubbles. (vi) After continuous stirring for $2 \mathrm{~h}$, the mixture was filtered and washed with $10 \% \mathrm{HCl}$ aqueous solution $(\sim 1000 \mathrm{~mL}, 250 \mathrm{~mL}$ x 4 times, Fisher Scientific) and a copious amount of deionized water to remove other ions until the $\mathrm{pH}$ reached 4 - 5. (vii) Finally, the resulting graphene powder was dried at $60-70{ }^{\circ} \mathrm{C}$ under vacuum for $24 \mathrm{~h}$. 


\subsection{Synthesis of $\mathrm{NiCO}_{2} \mathrm{O}_{4} / \mathrm{N}$-graphene catalyst}

The synthesized graphene powder was first pretreated by refluxing the material $(0.2 \mathrm{~g})$ in $50 \mathrm{~mL}$ of nitric acid at $80{ }^{\circ} \mathrm{C}$ for $4 \mathrm{~h}$. Then, the mixture was cooled to room temperature and diluted with $100 \mathrm{~mL}$ of de-ionized (DI) water. The resulting solid was collected by centrifugation, washed with deionized water for several times, and dried at $50{ }^{\circ} \mathrm{C}$ under vacuum.

For a typical synthesis in this study, $1.45 \mathrm{~mL}$ of $0.4 \mathrm{M} \mathrm{Ni}(\mathrm{OAc})_{2}$ and $1.94 \mathrm{~mL}$ of $0.6 \mathrm{M}$ $\mathrm{Co}(\mathrm{OAc})_{2}$ aqueous solution (molar ratio of $\mathrm{Ni}$ to $\mathrm{Co}$ is $1: 2$ ) were added to a $50 \mathrm{~mL}$ of ethanol solution with $0.2 \mathrm{~g}$ graphene suspension, followed by the addition of $5.0 \mathrm{~mL}$ of $\mathrm{NH}_{4} \mathrm{OH}$ at room temperature, which was used to promote the nucleation of the metal precursors and contribute a nitrogen source for doping.The reaction was maintained at $80^{\circ} \mathrm{C}$ under the continuous stir for 24 h. Then, the above reaction mixture was transferred to an $80 \mathrm{~mL}$ autoclave for hydrothermal reaction $\left(150{ }^{\circ} \mathrm{C}\right.$ for $\left.3 \mathrm{~h}\right)$ to obtain $\mathrm{N}$-doping and $\mathrm{NiCo}_{2} \mathrm{O}_{4}$ nanocrystals on graphene. The synthesized catalyst was then collected through centrifugation. Finally, the product was washed in sequences with water and ethanol. The $\mathrm{NiCo}_{2} \mathrm{O}_{4} / \mathrm{N}$-graphene composite product was $\sim 340 \mathrm{mg}$ after drying ( 41.2 wt. $\% \mathrm{NiCo}_{2} \mathrm{O}_{4}$ on graphene).

\subsection{Characterization of the $\mathrm{NiCo}_{2} \mathrm{O}_{4} / \mathrm{N}$-graphene catalyst}

Morphological characterization of the catalyst was carried out with a Hitachi S-5500 scanning transmission electron microscope (STEM). The elemental analysis results were obtained with an energy-dispersive spectrometer (EDS) attached to the Hitachi S-5500 STEM. The XRD data were collected on a Rigaku D/MAX-RC X-ray diffractometer equipped with $\mathrm{Cu}$ $\mathrm{K} \alpha$ radiation between $10^{\circ}$ and $80^{\circ}$ in a step of $0.02^{\circ}$. 


\subsection{Electrochemical measurements for the study of the ORR (oxygen reduction reaction) activity of the $\mathrm{NiCo}_{2} \mathrm{O}_{4} / \mathrm{N}$-graphene catalyst}

Cyclic Voltammetry (CV):10 mg of the powder catalyst was dispersed into a solution comprising of $800 \mu \mathrm{L}$ of deionized water, $200 \mu \mathrm{L}$ of isopropanol (IPA), and $18 \mu \mathrm{L}$ of Nafion solution (15 wt.\%) by sonication for $10 \mathrm{~min}$ to form a homogenious ink. Then, $5 \mu \mathrm{L}$ of the catalyst ink was loaded onto a glassy carbon electrode of $5 \mathrm{~mm}$ in diameter. Cyclic voltammetry was conducted with an Autolab potentiostat (PGSTAT128N) in a three-compartment cell with the catalyst-deposited glassy carbon as the working electrode, a Pt mesh as the counter electrode, and a saturated calomel electrode (SCE) as the reference electrode. The scan rate of the $\mathrm{CV}$ experiment was $5 \mathrm{mV} \mathrm{s}^{-1}$. The electrolyte was $1.0 \mathrm{M} \mathrm{KOH}$ solution which was bubbled with oxygen for $15 \mathrm{~min}$ before each experiment. An oxygen flow was also maintained over the electrolyte during the experiment to make sure that the electrolyte was always saturated with $\mathrm{O}_{2}$.

Rotating disk electrode ( $R D E$ ) experiment: The working electrodes for the RDE experiment were prepared the same way as for the CV experiment. Linear sweep voltage (LSV) experiments were also conducted with the Autolab potentiostat (PGSTAT128N) in a three-compartment cell with the catalyst-deposited glassy carbon as the working electrode, a Pt mesh as the counter electrode, and a saturated calomel electrode (SCE) as the reference electrode. The working electrode was scanned cathodically at a rate of $5 \mathrm{mV} \mathrm{s}^{-1}$ with varying rotating speed from 400 to $1600 \mathrm{rpm}$ controlled by a rotator (Pine Research Instrumentation).

Rotating Ring Disk Electrode (RRDE) Measurement: For the RRDE measurements, catalyst inks and electrodes were prepared by the same method as those for the RDE experiments. The disc electrode was scanned cathodically at a rate of $5 \mathrm{mV} \mathrm{s}^{-1}$, and the ring potential was 
constant at $1.3 \mathrm{~V}$ vs. RHE. The $\% \mathrm{HO}_{2}{ }^{-}$and the electron-transfer number $(n)$ were determined by the equations below:

$$
\begin{gathered}
O H_{2}^{-}=200 \times \frac{I_{r} / N}{I_{d}+I_{r} / N} \\
n=4 \times \frac{I_{d}}{I_{d}+I_{r} / N}
\end{gathered}
$$

where $I_{d}$ is the disk current, $I_{r}$ is the ring current, and $N$ is the current-collection efficiency of the Pt ring. $N$ was determined to be 0.38 from the reduction of $\mathrm{K}_{3} \mathrm{Fe}[\mathrm{CN}]_{6}$.

\subsection{Electrochemical measurements for the study of the FOR (fuel oxidation reaction) activities of the catalysts}

Preparation of the working electrodes:The catalysts used for these studies include $40 \%$ $\mathrm{PtRu} / \mathrm{C}\left(40\right.$ wt. \% Pt-Ru on Vulcan $\left.{ }^{\circledR} \mathrm{XC}-72\right)$ and the synthesized $\mathrm{NiCo}_{2} \mathrm{O}_{4} / \mathrm{N}$-graphene catalyst. The catalyst was first dispersed into deionized water followed by addition of a certain amount of Nafion solution (DuPont ${ }^{\circledR}$ ). The ratio of the catalyst to Nafion was maintained at $4: 1$ (mass ratio). Then the mixture was sonicated for $10 \mathrm{~min}$. Finally, the resulting slurry was sprayed onto a carbon fiber paper (Toray HP-60) and dried at room temperature for $1 \mathrm{~h}$ in air. The catalyst loading on the carbon paper was $1.6 \mathrm{mg} \mathrm{cm}^{-1}$ (including carbon support and Nafion).

FOR activity measurements: $\mathrm{CV}$ experiments were conducted in a traditional threecompartment electrochemical cell with a $\mathrm{HgO} / \mathrm{Hg}$ reference electrode and a $\mathrm{Pt}$ mesh counter electrode. The CV profiles were recorded with a potentiostat (VoltaLab PGZ 402, Radiometer Analytical) at ambient temperature. 


\subsection{Fuel cell performance test}

Preparation of anolytes: Methanol, ethanol, ethylene glycol, and glycerol (Fisher scientific $($ ) were dissolved into aqueous $\mathrm{KOH}$ solution to form the alkaline anolytes with $5.0 \mathrm{M}$ fuels (methanol, ethanol, ethylene glycol, or glycerol) and 2.0 $\mathrm{M} \mathrm{KOH}$.

Preparation of electrodes: The catalysts $\left(\mathrm{PtRu} / \mathrm{C}, \mathrm{MnCoNiO}_{4} / \mathrm{N}-\mathrm{MWCNT}\right.$, or $\mathrm{NiCo}_{2} \mathrm{O}_{4} / \mathrm{N}-$ graphene) were dispersed in a mixture of deionized water and a certain volume of Nafion solution (5\%, DuPont $\left.{ }^{\circledR}\right)$ by sonication for $10 \mathrm{~min}$. The mass ratio of net Nafion to the catalyst was $1: 4$ (mass ratio) in all cases. The resulting ink was deposited onto a carbon fiber paper (Toray HP-60) and dried in air for $1 \mathrm{~h}$ at room temperature. The catalyst loading at both the anode and the cathode were $2.6 \mathrm{mg} \mathrm{cm}^{-2}$ (including PtRu-alloy, $\mathrm{MnCoNiO}_{4}$, or $\mathrm{NiCo}_{2} \mathrm{O}_{4}$, not including the carbon support, MWCNT, or graphene) in all cases.

Fuel cell performance testing:An in-house designed membraneless alkaline DLFC (as schematized in Fig. S2 and S3) with $5.0 \mathrm{~cm}^{2}$ active area $(2.236 \mathrm{~cm} \times 2.236 \mathrm{~cm}$, the cathode and the anode were fabricated with identical area) and a $2 \mathrm{~mm}$ thick flow chamber (Fig. S3) was used for cell performance test. The cell was assembled as schematically described in Fig. S3. In order to prevent any catalyst-washout by the anolyte stream, two anolyte diffusion layers (made of Toray HP-60 carbon paper) were respectively applied to the anode and cathode side of the cell between the catalyst layers and the anolyte stream. In addition, two additional pieces of Toray HP-60 carbon paper were respectively placed to each side of the cell between the catalyst layers and the current collectors. The one at the cathode serves as a gas diffusion layer, and the other at the anode is used to protect the anode catalyst.

The operation of the DLFCs was performed with a fuel cell test station (850E, Scribner Associates Inc.) which could control the oxygen flow rate, humidity of the gas, temperature of 
the cell, and electrochemical testing parameters etc.). For the single-cell measurements, anolyte solutions were delivered through the cell chamber (Fig. S2 and S3) with a constant flow rate of

$1.0 \mathrm{~mL} \mathrm{~min}^{-1}$ (controlled with a peristaltic pump). To the cathode, $\mathrm{O}_{2}$ was fed at a flow rate of $100 \mathrm{~mL} \mathrm{~min}^{-1}$ (controlled by the fuel cell test station) without back pressure. The polarization profiles of the DLFCs were obtained by testing the cell in a constant current mode. In each case, the open-circuit voltage (OCV) was first recorded. Then, the voltage response of the cell was recorded upon the application of various currents (from low to high) to the cell. Each current applied was allowed to stabilize for $5 \mathrm{~min}$. The cell-test experiments were conducted at various temperatures.

\section{Results and Discussion}

\subsection{Principle of the membraneless alkaline DLFCs}

Generally in an alkaline DLFC, use of an AEM is a must to provide an $\mathrm{OH}^{-}$-ion transportation path and to prevent the mixing of the liquid fuel and the oxidants since the commonly used cathode catalysts (e. g., Pt) also catalyze the anode oxidation reaction. The philosophy of the proposed catalyst-selective strategy is illustrated in Fig. 1. By employing a non-Pt cathode catalyst with high activity for the ORR, but without any activity for the fuel oxidation reaction (FOR) (as schematized in Fig. 1a), the DLFCs would allow the anode fuel to freely enter the cathode, eliminating the need for an AEM in the cell. On the other hand, as a general scenario, the solubility and diffusivity of oxygen is fairly low in aqueous alkaline solutions [36, 37]. Therefore, the crossover of the cathode oxidant is not a significant issue. In addition, the ionic path between the anode and the cathode can be addressed by the addition of a supporting electrolyte (e.g., $\mathrm{KOH})$ to the anode fuel (to form an anolyte), which would sustain 
the conductivity of $\mathrm{OH}^{-}$ions. With proper management of the catalyst selectivity in the cell, a variety of organic liquids can be used as anode fuels. In addition, the catalyst-selective strategy allows operation of the membraneless DLFCs without any manipulation of the non-mixture laminar-flow of the fuel and the air, enabling the development of power-generation devices in flexible configurations without dimensional limitations.
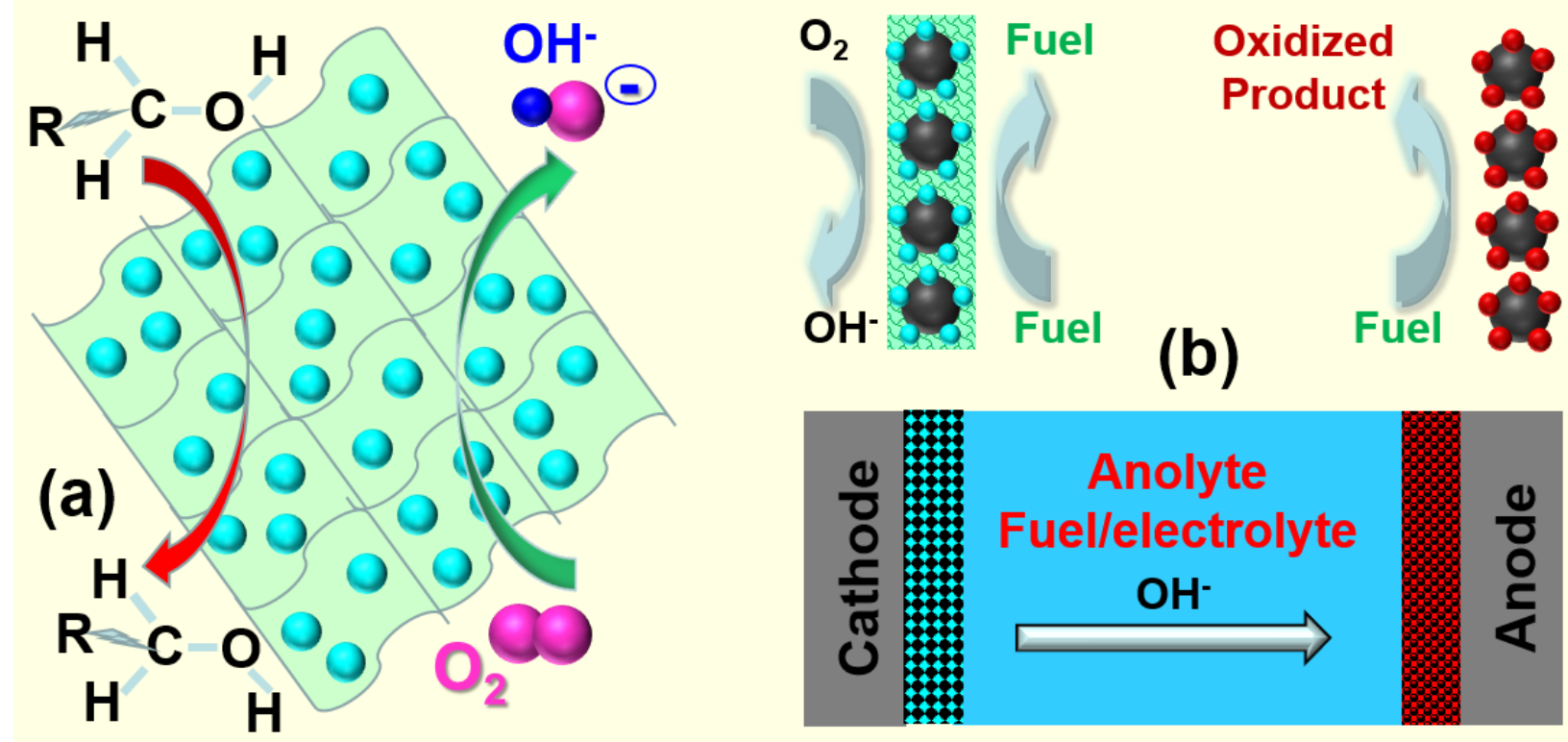

Fig. 1.(a) Schematic representation of a catalyst with a selective activity. (b) Schematic of a membraneless alkaline DLFC operated with a catalyst-selective principle.

\subsection{Material characterizations and $\mathrm{ORR}$ activity of the $\mathrm{NiCo}_{2} \mathrm{O}_{4} / \mathrm{N}$-graphene catalyst}

The key approach of this innovation is the logical management of the cathode/anode catalysts in the DLFCs, but the selectivity of the cathode catalyst plays the central role. The catalytic selectivity for the anode catalyst is not an obligation. In this study, we demonstrate the proposed platform by employing a reliable $\mathrm{PtRu} / \mathrm{C}$ (platinum-ruthenium alloy on carbon support) anode catalyst and with four renewable organic liquids as anode fuels including two alcohols (methanol and ethanol) and two poly-alcohols (ethylene glycol and glycerol). Half-cell reactions 
and the key properties of these organic liquids relevant to the fuel cell operation are provided in Table S1. These hydrogen-rich alcohols have the potential to provide high energy density DLFC systems with respect to their high intrinsic capacity and ability of multiple-electron charge transfer[38-42].

A non-Pt cathode catalyst $\mathrm{MnNiCoO}_{4} / \mathrm{N}-\mathrm{MWCNT}\left(\mathrm{MnNiCoO}_{4}\right.$ nano-particles on a nitrogen-doped multi-wall carbon nanotube) developed in our laboratory[34] is used to demonstrate the membraneless alkaline direct methanol fuel cell (DMFC) and direct ethanol fuel cell (DEFC). Owning to the chemical interaction between the N-doped carbon surface and the spinel oxide nanoparticles, this catalyst exhibits an excellent ORR activity that is almost comparable to that of Pt in alkaline medium[34], but is theoretically not expected to catalyze the oxidation reactions of the small-molecule organic liquids. Since the cathode catalyst plays the most important role in this innovation and in order to demonstrate that the proposed membraneless fuel cell concept can be developed with a wide range of catalysts, we developed a new cathode catalyst comprising binary transition-metal oxide nanoparticles on nitrogen-doped graphene $\left(\mathrm{NiCo}_{2} \mathrm{O}_{4} / \mathrm{N}\right.$-graphene) for the study of the membraneless alkaline direct ethylene glycol fuel cell (DEGFC) and direct glycerol fuel cell (DGFC). The N-doping usually promotes the ORR activity of the carbon-supported metal oxide catalysts from two aspects: (i) it helps to anchor the metal oxide nanoparticles on the carbon surfaceand (ii) N-doping promotes the oxygen absorption on the catalyst surface $[34,43,44]$.

Synthesis of the $\mathrm{NiCo}_{2} \mathrm{O}_{4} / \mathrm{N}$-graphene catalyst is mainly through an impregnationhydrothermal process as detailed in the experimental section. Fig. 2a shows the scanning transmission electron microscopy (STEM) image of the as-prepared catalyst, indicating the formation of the $\mathrm{NiCo}_{2} \mathrm{O}_{4}$ nanocrystals on graphene. The elemental analysis of the catalyst with 
the energy dispersive spectroscopy (EDS) (Fig. 2b) indicates that the atom ratio of Co : Ni in the $\mathrm{NiCo}_{2} \mathrm{O}_{4}$ nano-particles is $68: 32$, which is quite close to the targeted ratio of $2: 1$ in $\mathrm{NiCo}_{2} \mathrm{O}_{4}$. The X-ray diffraction (XRD) analysis of the $\mathrm{NiCo}_{2} \mathrm{O}_{4} / \mathrm{N}$-graphene composite (Fig. 2c) reveals that the synthesized $\mathrm{NiCo}_{2} \mathrm{O}_{4}$ has the cubic spinel structure.
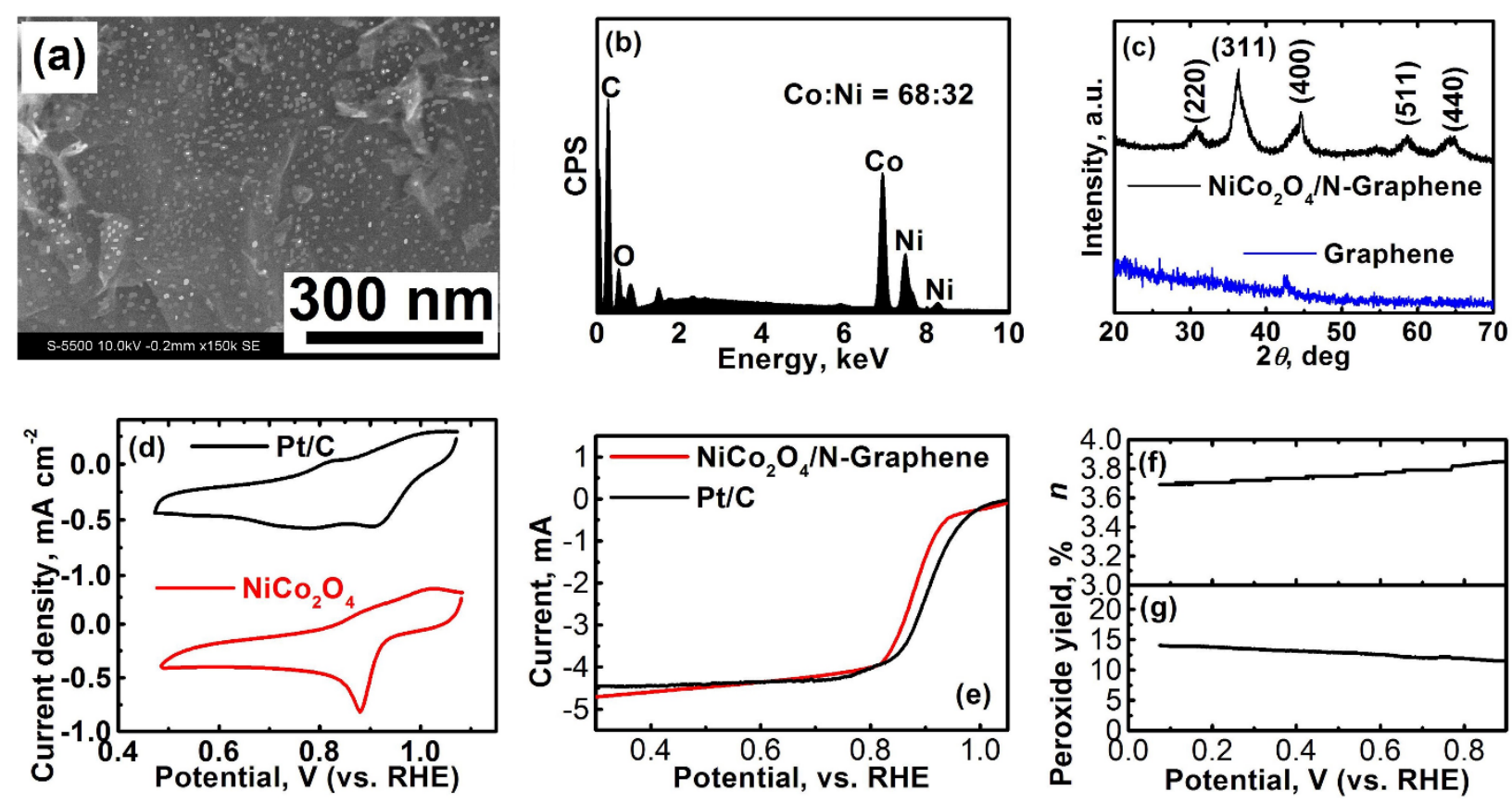

Fig. 2.(a) STEM image and (b) EDS spectrum of the $\mathrm{NiCo}_{2} \mathrm{O}_{4} / \mathrm{N}$-graphene catalyst. (c) XRD patterns of the pristine graphene and the $\mathrm{NiCo}_{2} \mathrm{O}_{4} / \mathrm{N}$-graphene catalyst. (d) Cyclic voltammetry profiles of the $\mathrm{Pt} / \mathrm{C}$ and the $\mathrm{NiCo}_{2} \mathrm{O}_{4} / \mathrm{N}$-graphene catalysts on in $1.0 \mathrm{M}$ potassium hydroxide solution saturated with $\mathrm{O}_{2}$. (e) Rotating-disk electrode voltammetry profiles (at $1600 \mathrm{rpm}$ ) of $\mathrm{Pt} / \mathrm{C}$ and $\mathrm{NiCo}_{2} \mathrm{O}_{4} / \mathrm{N}$-graphene catalysts in $1.0 \mathrm{M} \mathrm{KOH}$ solution saturated with $\mathrm{O}_{2}$ (the scan rate is $5 \mathrm{mV} \mathrm{s}^{-1}$ ). (f) The electron-transfer number $\mathrm{n}$ and (g) percentage of $\mathrm{O}_{2} \mathrm{H}^{-}$(relative to the total ORR products) yield on the $\mathrm{NiCo}_{2} \mathrm{O}_{4} / \mathrm{N}$-graphene catalyst at various potentials based on the corresponding RRDE results (provided in Fig. S5)

The ORR activity of the $\mathrm{NiCo}_{2} \mathrm{O}_{4} / \mathrm{N}$-graphene catalyst was fist evaluated with cyclic voltammetry $(\mathrm{CV})$ experiments performed in $1.0 \mathrm{M}$ potassium hydroxide $(\mathrm{KOH})$ solution and on a glassy carbon electrode. Fig. $2 \mathrm{~d}$ compares the $\mathrm{CV}$ profiles of the $\mathrm{NiCo}_{2} \mathrm{O}_{4} / \mathrm{N}$-graphene catalyst and the commercial $\mathrm{Pt} / \mathrm{C}$ (platinum nanoparticles on carbon support) catalyst under the same 
condition. The $\mathrm{NiCo}_{2} \mathrm{O}_{4} / \mathrm{N}$-graphene catalyst shows both the onset ORR potential ( $\sim 0.94 \mathrm{~V}$ vs. the reversible hydrogen electrode (RHE)) and the peak ORR potential ( $\sim 0.89 \mathrm{~V}$ vs. RHE) comparable to those for the $\mathrm{Pt} / \mathrm{C}$ catalyst ( $\sim 0.96 \mathrm{~V}$ and $0.91 \mathrm{~V}$ respectively). Both the onset ORR potential and the peak ORR potential are only $\sim 20 \mathrm{mV}$ more negative than those of the commercial Pt/C catalyst, suggesting that the electro-activity of the developed $\mathrm{NiCo}_{2} \mathrm{O}_{4} / \mathrm{N}$ graphene for ORR approaches that of the Pt/C under alkaline conditions.Fig. 2e compares the voltammetry profiles of the $\mathrm{NiCo}_{2} \mathrm{O}_{4} / \mathrm{N}$-graphene catalyst and the $\mathrm{Pt} / \mathrm{C}$ catalyst obtained with the rotating disc electrode (RDE) at a rotating rate of $1600 \mathrm{rpm}$; the detailed RDE profiles at different rotating speeds are provided in Fig. S4. The diffusion limiting currents of the two electrodes $\left(\mathrm{NiCo}_{2} \mathrm{O}_{4} / \mathrm{N}\right.$-graphene and $\left.\mathrm{Pt} / \mathrm{C}\right)$ are at almost the same level within the measured potential domain (Fig. 2e). In addition, the half-wave potential (at which the polarization wave current being equal to one half of the diffusion limiting current) of the $\mathrm{NiCo}_{2} \mathrm{O}_{4} / \mathrm{N}$-graphene catalyst is only $\sim 20 \mathrm{mV}$ less than that for the $\mathrm{Pt} / \mathrm{C}$ catalyst. The above direct comparisons imply that the $\mathrm{NiCo}_{2} \mathrm{O}_{4} / \mathrm{N}$-graphene can provide an ORR activity comparable to that of $\mathrm{Pt} / \mathrm{C}$.

Furthermore, the ORR pathway on the $\mathrm{NiCo}_{2} \mathrm{O}_{4} / \mathrm{N}$-graphene nano-composite was investigated by the rotating ring-disk electrode (RRDE). The voltammograms of the disk and ring obtained at $1600 \mathrm{rpm}$ are displayed in Fig. S5. Fig.s $2 \mathrm{f}$ and $2 \mathrm{~g}$, respectively, present the electron-transfer number (n) for ORR and the relative peroxide species yield on the catalyst during the RRDE experiment (percentage of $\mathrm{O}_{2} \mathrm{H}^{-}$over the total ORR products derived from the RRDE profiles in Fig. S5). The $\mathrm{O}_{2} \mathrm{H}^{-}$is $11-14 \%$ for the $\mathrm{NiCo}_{2} \mathrm{O}_{4} / \mathrm{N}$-graphene catalyst within the experimental potential range. The average $\mathrm{n}$ is ca. 3.8 for the $\mathrm{NiCo}_{2} \mathrm{O}_{4} / \mathrm{N}$-graphene catalyst, which approaches to the number for the Pt/C catalyst $[45,46]$. The above results indicate that the ORR catalyzed by the $\mathrm{NiCo}_{2} \mathrm{O}_{4} / \mathrm{N}$-graphene catalyst is mainly through the four-electron pathway. 


\subsection{Catalytic selectivity of the non-Pt catalysts comprising metal oxide nanoparticles coupled with nitrogen-doped carbon materials}

Fig. 3a and $\mathrm{b}$ demonstrate the FOR activity of the PtRu/C catalyst and the FOR inactivity of the $\mathrm{MnNiCoO}_{4} / \mathrm{N}-\mathrm{MWCNT}$ and the $\mathrm{NiCo}_{2} \mathrm{O}_{4} / \mathrm{N}$-graphene catalysts. On the $\mathrm{PtRu} / \mathrm{C}$ electrode, the oxidation current of methanol, ethanol, ethylene glycol, or glycerol increases in a nearly linear manor within the selected potential frame (-0.6 - $0.1 \mathrm{~V}$ vs. SHE) for the operation of the alkaline fuel cells. However, the $\mathrm{MnNiCoO}_{4} / \mathrm{N}-\mathrm{MWCNT}$ (Fig. 3a) and the $\mathrm{NiCo}_{2} \mathrm{O}_{4} / \mathrm{N}$-graphene (Fig. 3b) provide almost no activity for catalysing the oxidation reaction of the above organic liquid fuels. The FOR currents on either the $\mathrm{MnNiCoO}_{4} / \mathrm{N}-\mathrm{MWCNT}$ or the $\mathrm{NiCo}_{2} \mathrm{O}_{4} / \mathrm{N}$-graphene electrode is virtually exiguous in comparison to the FOR current yielded on the electrode with the PtRu/C catalyst.The mechanism regarding the FOR inactivity of the $\mathrm{MnNiCoO}_{4} / \mathrm{N}-\mathrm{MWCNT}$ and the $\mathrm{NiCo}_{2} \mathrm{O}_{4} / \mathrm{N}$-graphene catalysts is not very clear at the moment. It is mostly likely due to the lack of active sites for chemical absorption of the small organic molecules on the MnNiCoO $4 / \mathrm{N}-\mathrm{MWCNT}$ and $\mathrm{NiCo}_{2} \mathrm{O}_{4} / \mathrm{N}$-graphene catalysts. The relevant mechanistic studies will be performed in the future.
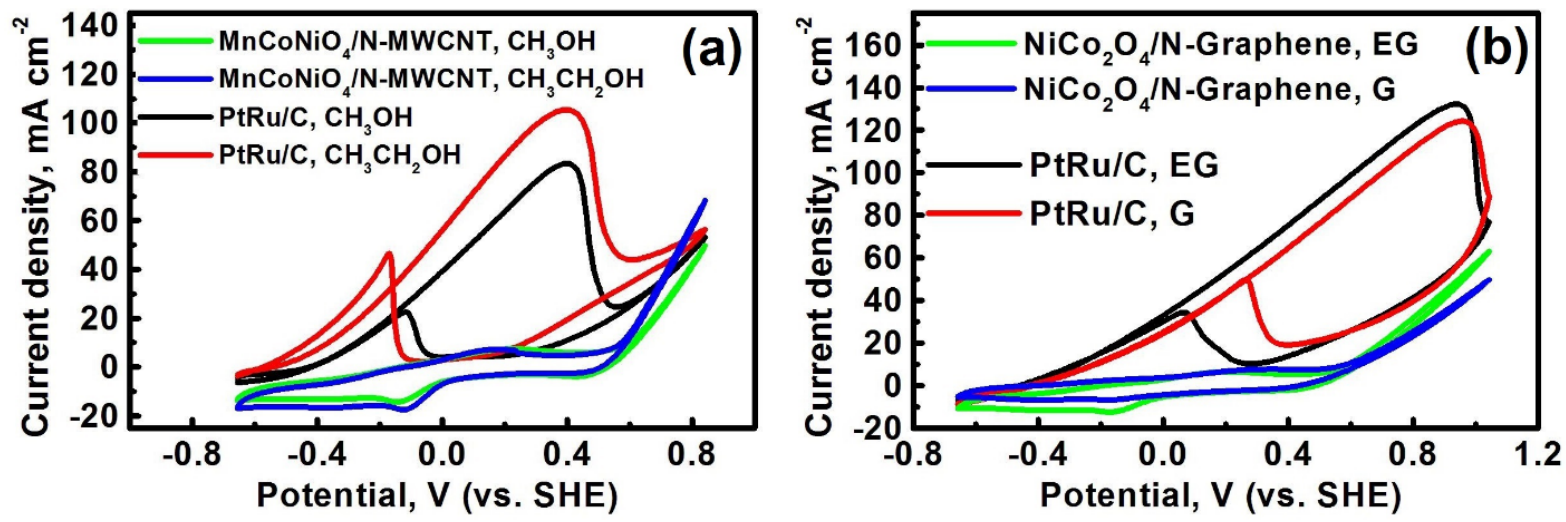

Fig. 3. Cyclic voltammograms $\left(10 \mathrm{mV} \mathrm{s}^{-1}\right)$ of (a) the $\mathrm{MnNiCoO}_{4} / \mathrm{N}-\mathrm{MWCNT}$ and $\mathrm{PtRu} / \mathrm{C}$ electrodes in the electrolyte containing either $1.0 \mathrm{M} \mathrm{CH} \mathrm{CH}_{3} \mathrm{OH}$ in $1.0 \mathrm{M} \mathrm{KOH}$ or $1.0 \mathrm{M}$ $\mathrm{CH}_{3} \mathrm{CH}_{2} \mathrm{OH}$ in $1.0 \mathrm{M} \mathrm{KOH}$, and (b) $\mathrm{NiCo}_{2} \mathrm{O}_{4} / \mathrm{N}$-graphene and $\mathrm{PtRu} / \mathrm{C}$ electrodes in the electrolyte containing either $1.0 \mathrm{M}$ ethylene glycol (EG) in $1.0 \mathrm{M} \mathrm{KOH}$ or $1.0 \mathrm{M}$ glycerol $(\mathrm{G})$ in $1.0 \mathrm{M} \mathrm{KOH}$. 


\subsection{Electrochemical performances of the membraneless DLFCs operated under catalyst- selective strategy}

According to the above catalytic selectivity, four membraneless alkaline DLFC systems DMFC, DEFC, DEGFC, and DGFC were developed without employing an AEM. The cell performances were tested with an in-house designed membraneless fuel cell (as illustrated in Fig. S2 and S3) in which an anolyte comprising either methanol, ethanol, ethylene glycol, or glycerol (as the liquid fuel) and potassium hydroxide (as a supporting electrolyte) was steadily fed as a flowing stream between the anode fuel diffusion layer and the cathode gas $\left(\mathrm{O}_{2}\right)$ diffusion layer. Fig. 4 presents the fuel cell performances of the four membraneless alkaline DLFCs under the specifications and operation conditions as briefly described in Table 1 and detailed in the supporting information. The key cell performance metrics (power density and current density at specific voltage) of the four fuel cell systems are also summarized in Table 1.

Table 1.Specifications and performances of the membraneless alkaline DMFC, DFFC,

DEGFC, and DGFC systems. The anolyte in each system contains $5.0 \mathrm{M}$ fuel and $2.0 \mathrm{M}$ KOH.

\begin{tabular}{|c|c|c|c|c|c|}
\hline $\begin{array}{l}\text { Membraneless } \\
\text { fuel cell system }\end{array}$ & $\begin{array}{c}\text { Fuel/ } \\
\text { anolyte }\end{array}$ & $\begin{array}{l}\text { Cathode } \\
\text { catalyst }\end{array}$ & $\begin{array}{l}\text { Anode } \\
\text { catalyst }\end{array}$ & $\begin{array}{l}\text { Maximum power } \\
\text { density, } \mathrm{mW} \mathrm{cm} \mathrm{cm}^{-2}\end{array}$ & $\begin{array}{l}\text { Current density at } \\
0.55 \mathrm{~V}, \mathrm{~mA} \mathrm{~cm}^{-2}\end{array}$ \\
\hline DMFC & $\begin{array}{l}\text { Methanol/ } \\
\mathrm{KOH}\end{array}$ & $\begin{array}{c}\mathrm{MnCoNiO}_{4} / \mathrm{N}- \\
\mathrm{MWCNT}\end{array}$ & $\mathrm{PtRu} / \mathrm{C}$ & $>90$ at $\left(65^{\circ} \mathrm{C}\right)$ & $\sim 100$ \\
\hline DEFC & $\begin{array}{l}\text { Ethanol/ } \\
\mathrm{KOH}\end{array}$ & $\begin{array}{c}\mathrm{MnCoNiO}_{4} / \mathrm{N}- \\
\mathrm{MWCNT}\end{array}$ & $\mathrm{PtRu} / \mathrm{C}$ & $>100\left(\right.$ at $\left.75^{\circ} \mathrm{C}\right)$ & $\sim 150$ \\
\hline DEGFC & $\begin{array}{c}\text { Ethylene glycol/ } \\
\mathrm{KOH}\end{array}$ & $\begin{array}{c}\mathrm{NiCo}_{2} \mathrm{O}_{4} / \mathrm{N}- \\
\text { graphene }\end{array}$ & $\mathrm{PtRu} / \mathrm{C}$ & $>80\left(\right.$ at $\left.75^{\circ} \mathrm{C}\right)$ & $\sim 100$ \\
\hline DGFC & $\begin{array}{c}\text { Glycol / } \\
\mathrm{KOH}\end{array}$ & $\begin{array}{c}\mathrm{NiCo}_{2} \mathrm{O}_{4} / \mathrm{N}- \\
\text { graphene }\end{array}$ & $\mathrm{PtRu} / \mathrm{C}$ & $>70\left(\right.$ at $\left.75^{\circ} \mathrm{C}\right)$ & $\sim 70$ \\
\hline
\end{tabular}



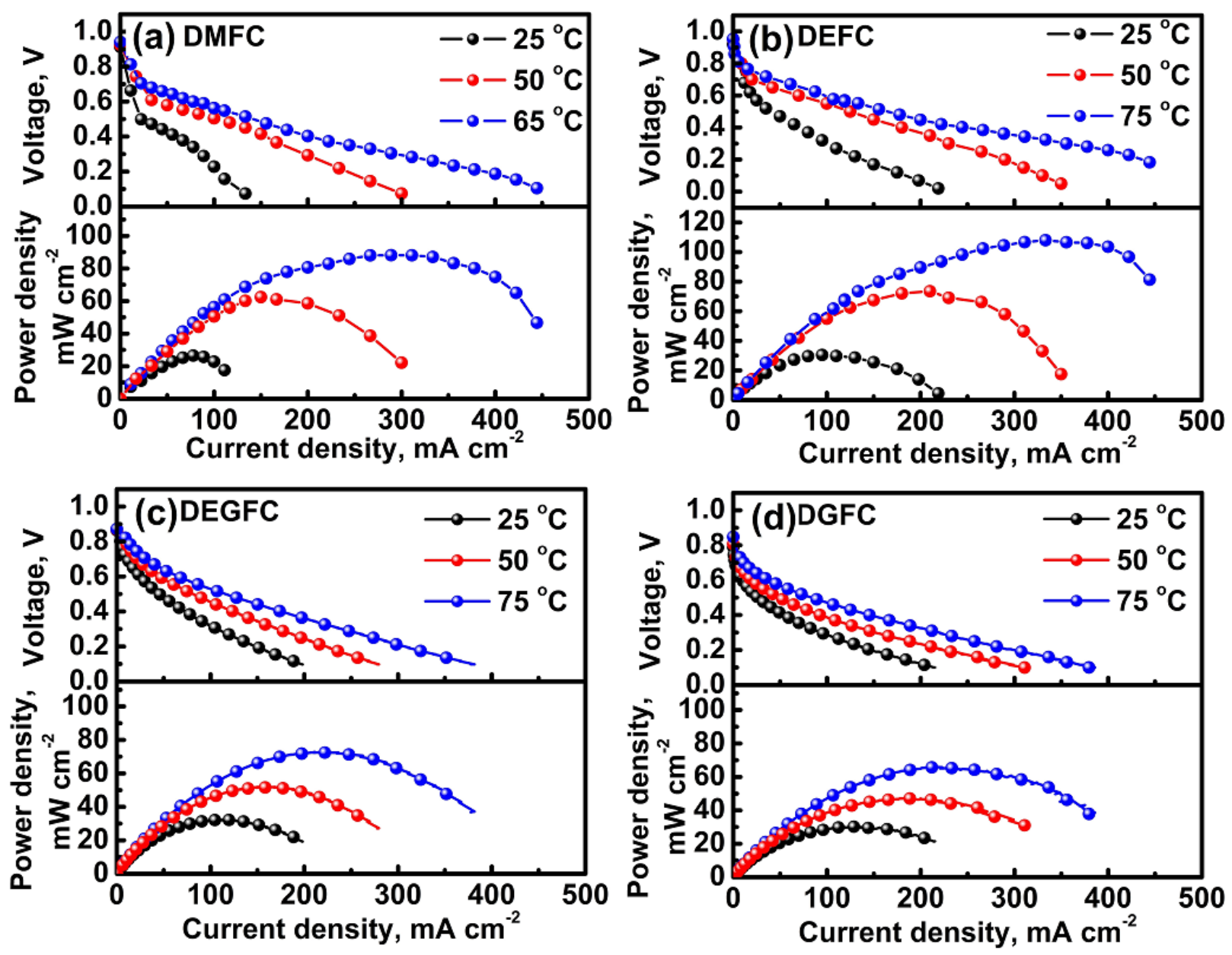

Fig. 4.Polarization curves and corresponding power plots of the membraneless alkaline direct liquid fuel cells (DLFCs) operated at different temperatures: (a) Direct methanol fuel cell (DMFC), (b) Direct ethanol fuel cell (DEFC), (c) Direct ethylene glycol fuel cell (DEGFC), and (d) Direct glycerol fuel cell (DGFC). The detailed cell specifications and operation conditions are provided in the supporting information.

Owing to the high ORR activity (almost comparable to that of Pt-based ORR catalyst under the alkaline conditions) and the FOR inactivity of the two cathode catalysts $\left(\mathrm{MnCoNiO}_{4} / \mathrm{N}\right.$ MWCNT and $\mathrm{NiCo}_{2} \mathrm{O}_{4} / \mathrm{N}$-graphene) employed here, the fuel cell performances of the membraneless alkaline DLFCs demonstrated in this study (Fig. 4 and Table 1) are comparable/superior to those of traditional DMFCs, DEFCs, DEGFCs, and DGFCs with the $\mathrm{H}^{+}-$ PEMs or the $\mathrm{OH}^{-}-\mathrm{AEMs}$, which are operated with a high-loading Pt cathode catalyst[47-50].The 
peak power densities of thesecatalyst-selective membraneless DLFCs are also comparable/superior to those of the liquid/gaseous or liquid/liquid co-laminar flow membraneless fuel cells [9-11, 15, 51-54].However, some liquid/liquid co-laminar flow fuel cells with alternative oxidants (rather than oxygen or air) can provide even higher peak power density $[55,56]$. Since there is no mixed potential concerns in the catalyst-selective DLFCs, the opencircuit voltages (OCV) of the demonstrated DLFCs (Fig. 4) are relatively closer to their theoretical value in comparison to those of the traditional DLFCs [47-50]. Under the conditions shown in Table 1, the operation temperatures of each DLFC system are below the boiling points of the fuels and water. Therefore, the fuel cells can run safely. In addition to the high maximum power densities (around or approaching $100 \mathrm{~mW} \mathrm{~cm}^{-2}$ under reasonably low temperatures without the Pt cathode catalyst) obtained with the four membraneless DLFC systems, the current densities at $0.55 \mathrm{~V}\left(\sim 100 \mathrm{~mA} \mathrm{~cm}{ }^{-2}\right.$ for DMFC and DEGFC, $\sim 150 \mathrm{~mA} \mathrm{~cm}^{-2}$ for DEFC $)$ of the DLFCs are also impressive for the modular development of the power systems. Also, it should be noted that the cell performance could be further improved in the future by optimizing the catalysts (both the anode and the catalysts, as well as their loadings), the cell configurations (including the gas diffusion layer, thickness of the anolyte-flow chamber etc.), and the operating conditions (such as the concentration of the fuel, supporting electrolyte, flow rate of anolytes, flow rate of air, operating temperature etc.).

In the traditional DLFCs, even with a $\mathrm{H}^{+}$-PEM or a $\mathrm{OH}^{-}-\mathrm{AEM}$, the anode fuel (especially at high concentrations) on the anodic side has the tendency to diffuse through the membrane to the cathode, where it is rapidly oxidized on the cathode catalyst (e.g., Pt). Such a fuel cross-over behavior which has a significantly negative effect on cell performance (due to a mixed potentials at the cathode and the loss of the fuel reaction at the anode) can be absolutely eliminated by the 
proposed catalyst-selective strategy. Therefore, the membraneless DLFCs demonstrated in this report show enhanced performance in contrast to those traditional membrane-based DLFCs.

\subsection{Perspective of the membraneless DLFC platform}

From the encouraging results presented so far, it is clear that high-power DLFCs can be developed with inexpensive, organic liquid fuels and non-platinum cathode catalysts without the need for the expensive or difficult-to-develop ion-change membranes and without any fuel crossover concerns. Furthermore, based on its unique working principle, the catalyst-selective strategy would allow the development of the DLFCs without dimensional limitations in flexible configurations. With the above advantageous features, the membraneless alkaline DLFCs operated under the catalyst-selective strategy overcome the limitations existing with the conventional PEM-based DLFCs, AEM-based DLFCs, and laminar-flow membraneless DLFCs.

Although the proposed platform was demonstrated with only the DMFC, DEFC, DEGFC, and DGFC systems, the "catalyst-selective DLFCs" can be expanded to a broad range of energygeneration systems with a vast range of inexpensive, non-hazardous fuels through a proper exploration of the anode/cathode catalysts and logical managements of the catalyst selectivity. In this regard, the "catalyst-selective strategy" along with the previously proposed concept of "mixed reactant fuel cell" provides new insights to develop membraneless DLFCs, which is expected to have an important impact on next-generation clean energy conversion/generation technologies. The unique features of the membraneless DLFC systems will enable the development of small, safe, low-cost mobile power sources and the energy conversion/generation devices in larger scale for electric vehicle and stationary applications. 
One potential issue for the operation of the membranelesss alkaline DLFCs is the poisoning of the electrolyte by $\mathrm{CO}_{2}$. In addition to the $\mathrm{CO}_{2}$ from ambient air similar to the common issue associated with the traditional alkaline fuel cells, the oxidation of the liquid anode fuels introduces an additional source of electrolyte carbonation $\left(\mathrm{CO}_{2}\right.$ generated in-situ). The $\mathrm{CO}_{2}$ issue from ambient air at the cathode can be easily mitigated bypurifying the air with a " $\mathrm{CO}_{2}-$ scrubber." For the in-situ generated $\mathrm{CO}_{2}$ from the oxidation of the anode fuels, the following technical/engineering approaches/strategies are expected to be effective: (i) replenishment of the spent alkaline electrolyte on a regular maintenance schedule; (ii) application of a " $\mathrm{CO}_{2}-$ absorption layer" at the anode side to prevent the fuel oxidation product $\left(\mathrm{CO}_{2}\right)$ from getting into the main stream of the anolyte; and (iii)intermittently regenerate the anolyte by employing a "porous filter" which is filled with the $\mathrm{Ca}^{2+}$-ion or $\mathrm{Mg}^{2+}$-ion salts. Since the in-situ generated $\mathrm{CO}_{2}$ is a commonly important issue of the alkaline DLFCs, it may need great efforts from the entire alkaline fuel cell community to address this problem. Our on-going and future work includes the development of proper techniques to solve the anolyte-poisoning problem (by the in-situ generated $\mathrm{CO}_{2}$ ). In addition, we are planning to explore non-precious metal-based anode catalysts to replace the conventional $\mathrm{PtRu} / \mathrm{C}$ used in this study, which can further reduce the overall cost of the membraneless DLFCs.

\section{Conclusions}

In summary, we presented a membraneless direct liquid fuel cell (DLFC) platform operating under alkaline conditions and at low temperatures with a catalyst-selective strategy. Non-platinum cathode catalysts based on the strongly coupled transition-metal-oxide nanocrystals and nano-structured carbon materials have been used for this innovation due to their 
high catalytic selectivity. The catalyst-selective principle circumvents the reliance on the expensive or practically difficult-to-develop ion-exchange membranes in the traditional DLFCs. Also importantly, it avoids the process-scale-up issue of the conventional laminar-flow membraneless DLFCs and provide a facile approach for development of membraneless DLFCs in large scales and with flexible/simple cell configurations. With proper management of the catalyst selectivity in the cell, a variety of inexpensive alcohols/polyalcohols and other smallmolecule organic liquids can be used as anode fuels.

\section{Acknowledgements}

This work was supported by the Welch Foundation grant F-1254. E .J. P and J. C. W. were supported by the Research Experience for Undergraduates (REU) program of the National Science Foundation Materials Interdisciplinary Research Team (MIRT) grant DMR-1122603.

\section{Appendix A. Supplementary material}

Supplementary data associated with this article can be found in the online version at http://dx.doi.org/10.1016/j.jpowsour.(will be filled in by the editorial staff).

\section{References:}

[1] X.W. Yu, S.Y. Ye, J Power Sources, 172 (2007) 133-144.

[2] X.W. Yu, S.Y. Ye, J Power Sources, 172 (2007) 145-154.

[3] T.R. Ralph, M.P. Hogarth, Platin Met Rev, 46 (2002) 117-135.

[4] R. Hiesgen, D. Eberhardt, E. Aleksandrova, K.A. Friedrich, Fuel Cells, 6 (2006) 425-431.

[5] R. Zeng, J. Handsel, S.D. Poynton, A.J. Roberts, R.C.T. Slade, H. Herman, D.C. Apperley, J.R. Varcoe, Energ Environ Sci, 4 (2011) 4925-4928.

[6] J.R. Varcoe, R.C.T. Slade, Fuel Cells, 5 (2005) 187-200.

[7] S.A.M. Shaegh, N.T. Nguyen, S.H. Chan, Int J Hydrogen Energ, 36 (2011) 5675-5694.

[8] M.A. Goulet, E. Kjeang, J Power Sources, 260 (2014) 186-196. 
[9] S. Hasegawa, K. Shimotani, K. Kishi, H. Watanabe, Electrochem Solid State Lett, 8 (2005) A119-A121.

[10] R. Ferrigno, A.D. Stroock, T.D. Clark, M. Mayer, G.M. Whitesides, J Am Chem Soc, 124 (2002) 12930-12931.

[11] E. Kjeang, A.G. Brolo, D.A. Harrington, N. Djilali, D. Sinton, J Electrochem Soc, 154 (2007) B1220-B1226.

[12] W. Sung, J.W. Choi, J Power Sources, 172 (2007) 198-208.

[13] D.T. Whipple, R.S. Jayashree, D. Egas, N. Alonso-Vante, P.J.A. Kenis, Electrochim Acta, 54 (2009) 4384-4388.

[14] S. Tominaka, S. Ohta, H. Obata, T. Momma, T. Osaka, J Am Chem Soc, 130 (2008) 1045610457.

[15] E.R. Choban, J.S. Spendelow, L. Gancs, A. Wieckowski, P.J.A. Kenis, Electrochim Acta, 50 (2005) 5390-5398.

[16] R.S. Jayashree, S.K. Yoon, F.R. Brushett, P.O. Lopez-Montesinos, D. Natarajan, L.J.

Markoski, P.J.A. Kenis, J Power Sources, 195 (2010) 3569-3578.

[17] B. Ho, E. Kjeang, J Fluid Eng, 135 (2013) 021304.

[18] K.S. Salloum, J.D. Posner, J Power Sources, 196 (2011) 1229-1234.

[19] A.K. Shukla, R.K. Raman, K. Scott, Fuel Cells, 5 (2005) 436-447.

[20] S.C. Barton, T. Patterson, E. Wang, T.F. Fuller, A.C. West, J Power Sources, 96 (2001) 329-336.

[21] M.A. Priestnall, V.P. Kotzeva, D.J. Fish, E.M. Nilsson, J Power Sources, 106 (2002) 21-30.

[22] R.K. Raman, G. Murgia, A.K. Shukla, J Appl Electrochem, 34 (2004) 1029-1038.

[23] M.K. Ravikumar, A.K. Shukla, J Electrochem Soc, 143 (1996) 2601-2606.

[24] H. Bonnemann, W. Brijoux, R. Brinkmann, E. Dinjus, T. Joussen, B. Korall, Angewandte

Chemie. Int, 30 (1991) 1312-1314.

[25] S.H. Sun, C.B. Murray, D. Weller, L. Folks, A. Moser, Science, 287 (2000) 1989-1992.

[26] A.K. Shukla, M. Neergat, P. Bera, V. Jayaram, M.S. Hegde, J Electroanal Chem, 504 (2001)

111-119.

[27] M. Neergat, A.K. Shukla, K.S. Gandhi, J Appl Electrochem, 31 (2001) 373-378.

[28] G.Q. Sun, J.T. Wang, R.F. Savinell, J Appl Electrochem, 28 (1998) 1087-1093.

[29] S. Gupta, D. Tryk, S.K. Zecevic, W. Aldred, D. Guo, R.F. Savinell, J Appl Electrochem, 28 (1998) 673-682.

[30] V. Trapp, P. Christensen, A. Hamnett, J Chem Soc Faraday T, 92 (1996) 4311-4319.

[31] C. Fischer, N. Alonsovante, S. Fiechter, H. Tributsch, J Appl Electrochem, 25 (1995) 10041008.

[32] R.W. Reeve, P.A. Christensen, A. Hamnett, S.A. Haydock, S.C. Roy, J Electrochem Soc, 145 (1998) 3463-3471.

[33] P.J. Sebastian, F.J. Rodriguez, O. Solorza, R. Rivera, J New Mat Electro Sys, 2 (1999) $115-$ 119.

[34] X.W. Yu, A. Manthiram, Catal Sci Technol, 5 (2015) 2072-2075.

[35] X.W. Yu, A. Manthiram, Appl Catal B-Environ, 165 (2015) 63-67.

[36] K.E. Gubbins, R.D. Walker, J Electrochem Soc, 112 (1965) 469-\&.

[37] R.E. Davis, G.L. Horvath, C.W. Tobias, Electrochim Acta, 12 (1967) 287-\&.

[38] Z.Y. Zhang, L. Xin, W.Z. Li, Appl Catal B-Environ, 119 (2012) 40-48.

[39] X.T. Han, D.J. Chadderdon, J. Qi, L. Xin, W.Z. Li, W. Zhou, Int J Hydrogen Energy, 39 (2014) 19767-19779. 
[40] A. Serov, C. Kwak, Appl Catal B-Environ, 97 (2010) 1-12.

[41] Y. Zhou, Q.J. Xu, Adv Mater Res-Switz, 860-863 (2014) 797-800.

[42] J.N. Tiwari, R.N. Tiwari, G. Singh, K.S. Kim, Nano Energy, 2 (2013) 553-578.

[43] Y. Liang, H. Wang, L. Xie, P. Diao, J. Zhou, J. Wang, W. Chang, T.Z. Regier, G. Hong, F. Wei, Y. Li, H. Dai, J Am Chem Soc, 134 (2012) 15849-15857.

[44] Y. Liang, J. Zhou, Y. Li, J. Wang, T. Regier, H. Dai, J Am Chem Soc, 134 (2012) 3517-3523.

[45] E. Yeager, Electrochim Acta, 29 (1984) 1527-1537.

[46] J.S. Spendelow, A. Wieckowski, Phys Chem Chem Phys, 9 (2007) 2654-2675.

[47] Z.Y. Zhang, L. Xin, W.Z. Li, Int J Hydrogen Energ, 37 (2012) 9393-9401.

[48] L. An, L. Zeng, T.S. Zhao, Int J Hydrogen Energ, 38 (2013) 10602-10606.

[49] E.H. Yu, U. Krewer, K. Scott, Energies, 3 (2010) 1499-1528.

[50] C. Bianchini, P.K. Shen, Chem Rev, 109 (2009) 4183-4206.

[51] S.K.Y. Ranga S. Jayashreea, F.R. Brushett, P.O. Lopez-Montesinos, D. Natarajanc, L.J. Markoski P.J.A. Kenis, J Power Sources, 195 (2010) 3569-3578.

[52] L.R.A. Zebda, M. Cretin, F. Pichot, C. Innocent, R. Ferrigno, S. Tingry, Electrochem Commun, 11 (2009) 592-595.

[53] E.K. J.W. Lee, Int J Hydrogen Energy, 37 (2012) 9359-9367.

[54] A.F. C. Xu, X. Li, T. Ward, Int J Hydrogen Energy, 35 (2010) 1769-1777.

[55] D.F.N. Mota, J. Kirtland, C. Rodriguez, A. Stroock, H. Abruna,J Am Chem Soc, 134 (2012) 6076-6079.

[56] H.Z. P. Zhao, H. Zhou, J. Chen, S. Gao, B. Yi, J Power Sources 162 (2006) 1416-1142. 
Table 1.Specifications and performances of the membraneless alkaline DMFC, DFFC, DEGFC, and DGFC systems

\begin{tabular}{|c|c|c|c|c|c|}
\hline $\begin{array}{l}\text { Membraneless } \\
\text { fuel cell system }\end{array}$ & $\begin{array}{c}\text { Fuel/ } \\
\text { anolyte }\end{array}$ & $\begin{array}{l}\text { Cathode } \\
\text { catalyst }\end{array}$ & $\begin{array}{l}\text { Anode } \\
\text { catalyst }\end{array}$ & $\begin{array}{l}\text { Maximum power } \\
\text { density, } \mathrm{mW} \mathrm{cm}\end{array}$ & $\begin{array}{l}\text { Current density at } \\
0.55 \mathrm{~V}, \mathrm{~mA} \mathrm{~cm}^{-2}\end{array}$ \\
\hline DMFC & $\begin{array}{c}\text { Methanol/ } \\
\mathrm{KOH}\end{array}$ & $\begin{array}{c}\mathrm{MnCoNiO}_{4} / \mathrm{N}- \\
\mathrm{MWCNT}\end{array}$ & $\mathrm{PtRu} / \mathrm{C}$ & $>90$ at $\left(65^{\circ} \mathrm{C}\right)$ & $\sim 100$ \\
\hline DEFC & $\begin{array}{c}\text { Ethanol/ } \\
\mathrm{KOH}\end{array}$ & $\begin{array}{c}\mathrm{MnCoNiO}_{4} / \mathrm{N}- \\
\mathrm{MWCNT}\end{array}$ & $\mathrm{PtRu} / \mathrm{C}$ & $>100\left(\right.$ at $\left.75^{\circ} \mathrm{C}\right)$ & $\sim 150$ \\
\hline DEGFC & $\begin{array}{c}\text { Ethylene glycol/ } \\
\mathrm{KOH}\end{array}$ & $\begin{array}{c}\mathrm{NiCo}_{2} \mathrm{O}_{4} / \mathrm{N}- \\
\text { graphene }\end{array}$ & $\mathrm{PtRu} / \mathrm{C}$ & $>80\left(\right.$ at $\left.75^{\circ} \mathrm{C}\right)$ & $\sim 100$ \\
\hline DGFC & $\begin{array}{c}\text { Glycol / } \\
\mathrm{KOH}\end{array}$ & $\begin{array}{c}\mathrm{NiCo}_{2} \mathrm{O}_{4} / \mathrm{N}- \\
\text { graphene }\end{array}$ & $\mathrm{PtRu} / \mathrm{C}$ & $>70\left(\right.$ at $\left.75^{\circ} \mathrm{C}\right)$ & $\sim 70$ \\
\hline
\end{tabular}




\section{Figure Captions}

Fig. 1.(a) Schematic representation of a catalyst with a selective activity. (b) Schematic of a membraneless alkaline DLFC operated with a catalyst-selective principle.

Fig. 2.(a) STEM image and (b) EDS spectrum of the $\mathrm{NiCo}_{2} \mathrm{O}_{4} / \mathrm{N}$-graphene catalyst. (c) XRD patterns of the pristine graphene and the $\mathrm{NiCo}_{2} \mathrm{O}_{4} / \mathrm{N}$-graphene catalyst. (d) Cyclic voltammetry profiles of the $\mathrm{Pt} / \mathrm{C}$ and the $\mathrm{NiCo}_{2} \mathrm{O}_{4} / \mathrm{N}$-graphene catalysts on in $1.0 \mathrm{M}$ potassium hydroxide solution saturated with O2. (e) Rotating-disk electrode voltammetry profiles (at $1600 \mathrm{rpm}$ ) of $\mathrm{Pt} / \mathrm{C}$ and $\mathrm{NiCo}_{2} \mathrm{O}_{4} / \mathrm{N}$-graphene catalysts in $1.0 \mathrm{M} \mathrm{KOH}$ solution saturated with $\mathrm{O} 2$ (the scan rate is $5 \mathrm{mV} \mathrm{s}^{-1}$ ). (f) The electron-transfer number $\mathrm{n}$ and (g) percentage of $\mathrm{HO}^{-}$(relative to the total ORR products) yield on the $\mathrm{NiCo}_{2} \mathrm{O}_{4} / \mathrm{N}$-graphene catalyst at various potentials based on the corresponding RRDE results (provided in Fig. S5).

Fig. 3. Cyclic voltammograms $\left(10 \mathrm{mV} \mathrm{s}^{-1}\right)$ of (a) the $\mathrm{MnNiCoO}_{4} / \mathrm{N}-\mathrm{MWCNT}$ and $\mathrm{PtRu} / \mathrm{C}$ electrodes in the electrolyte containing either $1.0 \mathrm{M} \mathrm{CH} \mathrm{CH}_{3} \mathrm{OH}$ in $1.0 \mathrm{M} \mathrm{KOH}$ or $1.0 \mathrm{M}$ $\mathrm{CH}_{3} \mathrm{CH}_{2} \mathrm{OH}$ in $1.0 \mathrm{M} \mathrm{KOH}$, and (b) $\mathrm{NiCo}_{2} \mathrm{O}_{4} / \mathrm{N}$-graphene and $\mathrm{PtRu} / \mathrm{C}$ electrodes in the electrolyte containing either 1.0 M ethylene glycol (EG) in $1.0 \mathrm{M} \mathrm{KOH}$ or $1.0 \mathrm{M}$ glycerol (G) in $1.0 \mathrm{M} \mathrm{KOH}$.

Fig. 4. Polarization curves and corresponding power plots of the membraneless alkaline direct liquid fuel cells (DLFCs) operated at different temperatures: (a) Direct methanol fuel cell (DMFC), (b) Direct ethanol fuel cell (DEFC), (c) Direct ethylene glycol fuel cell (DEGFC), and (d) Direct glycerol fuel cell (DGFC). The detailed cell specifications and operation conditions are provided in the supporting information. 

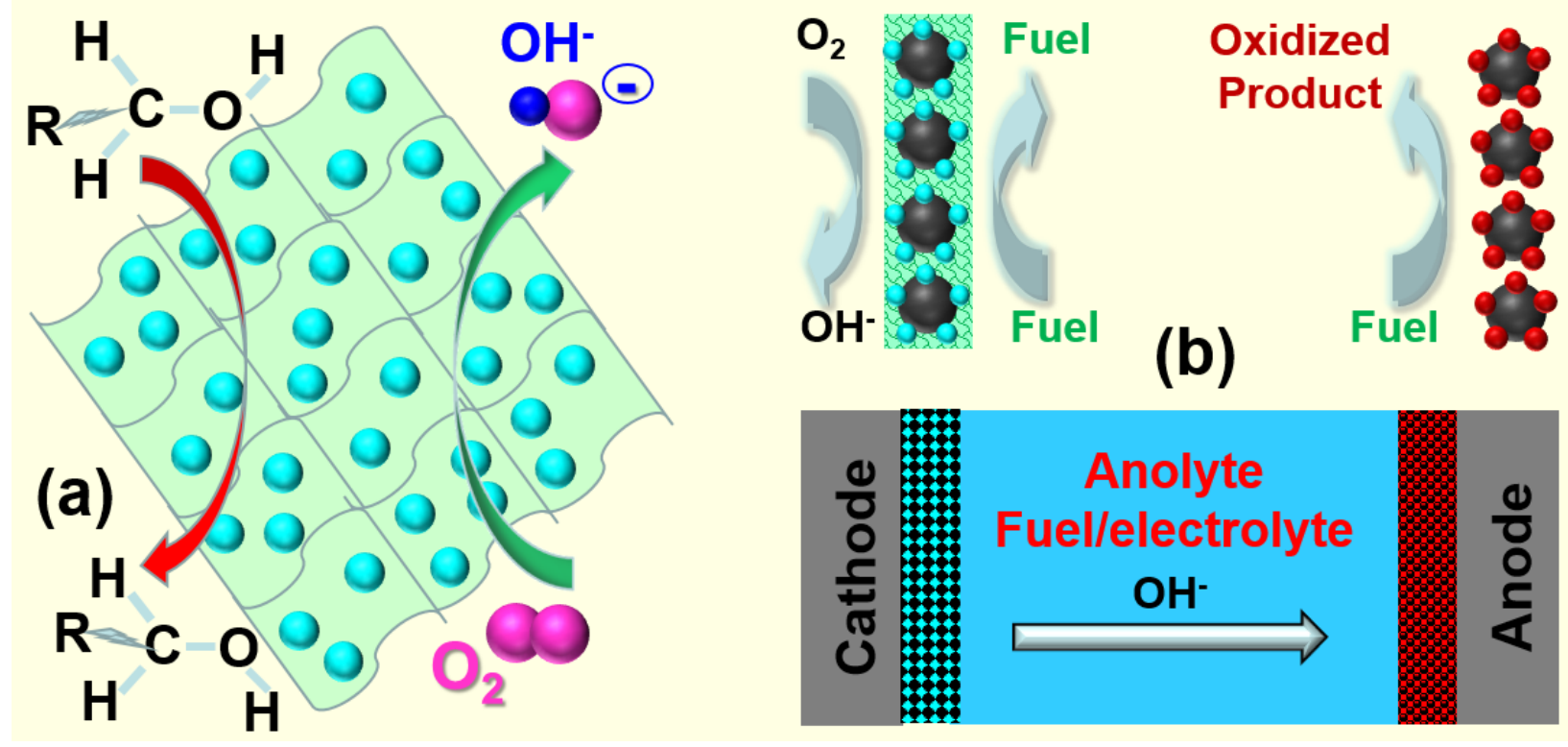

Fig. 1 

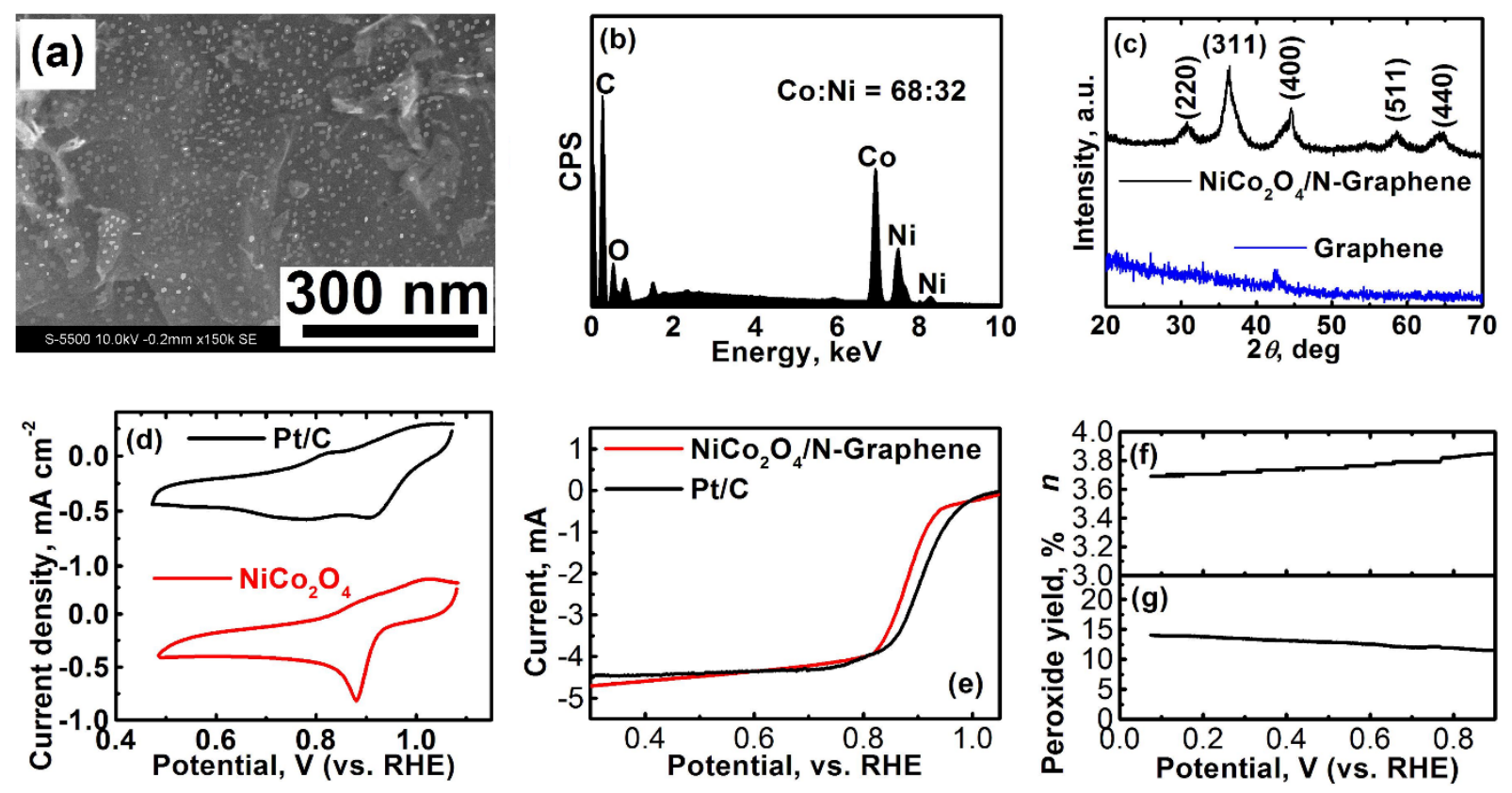

Fig. 2 

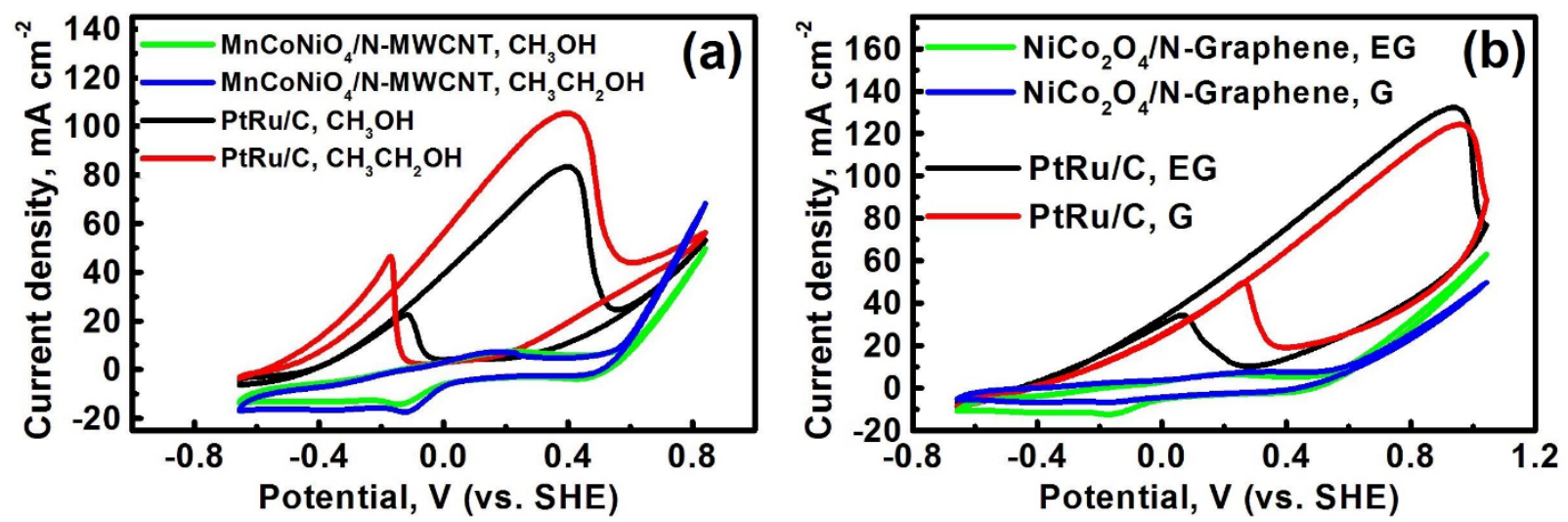

Fig. 3 

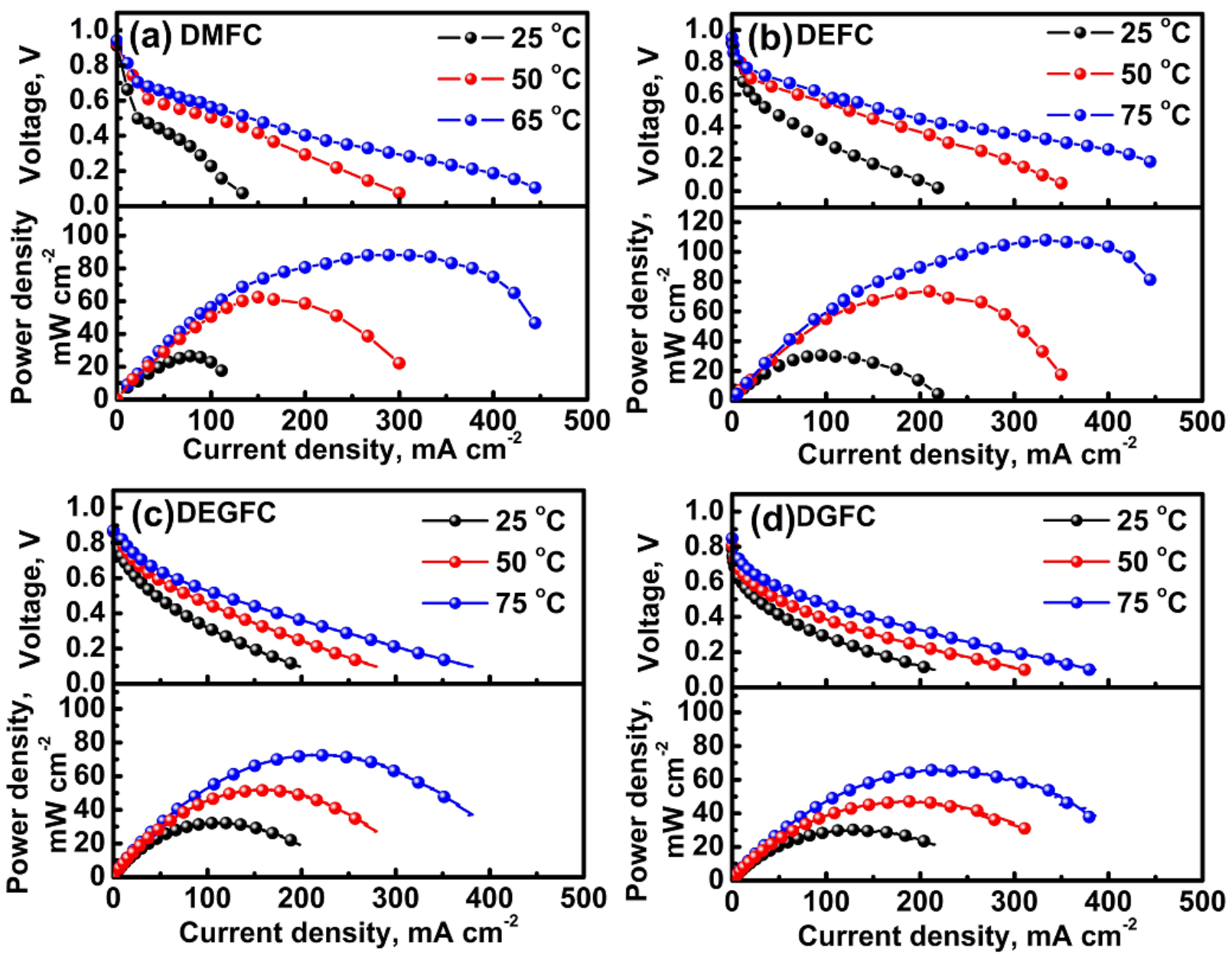

Fig. 4 